\title{
Management of acromegaly in Latin America: expert panel recommendations
}

\author{
Ariel Barkan • Marcello D. Bronstein • Oscar D. Bruno • Alejandro Cob • \\ Ana Laura Espinosa-de-los-Monteros • Monica R. Gadelha • Gloria Garavito • \\ Mirtha Guitelman · Ruth Mangupli • Moisés Mercado • Lesly Portocarrero • \\ Michael Sheppard
}

Published online: 31 October 2009

(C) The Author(s) 2009. This article is published with open access at Springerlink.com

\begin{abstract}
Although there are international guidelines orienting physicians on how to manage patients with acromegaly, such guidelines should be adapted for use in distinct regions of the world. A panel of neuroendocrinologists convened in Mexico City in August of 2007 to discuss specific considerations in Latin America. Of major discussion was the laboratory evaluation of acromegaly, which requires the use of appropriate tests and the adoption of local institutional standards. As a general rule to ensure diagnosis, the patient's GH level during an oral glucose tolerance test and IGF-1 level should be evaluated. Furthermore, to guide treatment decisions, both GH and IGF-1 assessments are required. The treatment of patients with acromegaly in Latin America is influenced by local issues of cost, availability and expertise of pituitary neurosurgeons, which should dictate therapeutic choices. Such
\end{abstract}

A. Barkan

The University of Michigan, Ann Arbor, MI, USA

M. D. Bronstein

Hospital das Clínicas, University of São Paulo Medical School, São Paulo, Brazil

O. D. Bruno

Hospital de Clínicas José de San Martín, UBA, Buenos Aires, Argentina

\section{A. $\mathrm{Cob}$}

Hospital San Juan de Dios, San José, Costa Rica

\section{A. L. Espinosa-de-los-Monteros · M. Mercado $(\square)$}

Endocrinology Unit, Hospital de Especialidades del Centro

Médico Nacional Siglo XXI, del Instituto Mexicano del Seguro

Social (IMSS), Aristóteles \# 68, Col. Polanco, CP 115560

Mexico City, Mexico

e-mail: mmercadoa@yahoo.com;

moises.mercado@imss.gob.mx treatment has undergone profound changes because of the introduction of effective medical interventions that may be used after surgical debulking or as first-line medical therapy in selected cases. Surgical resection remains the mainstay of therapy for small pituitary adenomas (microadenomas), potentially resectable macroadenomas and invasive adenomas causing visual defects. Radiotherapy may be indicated in selected cases when no disease control is achieved despite optimal surgical debulking and medical therapy, when there is no access to somatostatin analogues, or when local issues of cost preclude other therapies. Since not all the diagnostic tools and treatment options are available in all Latin American countries, physicians need to adapt their clinical management decisions to the available local resources and therapeutic options.

M. R. Gadelha

Universidade Federal do Rio de Janeiro, Rio de Janeiro, Brazil

G. Garavito

Instituto Nacional de Cancerología, Bogotá, Colombia

\section{Guitelman}

División Endocrinología, Hospital General de Agudos Carlos G.

Durand, Buenos Aires, Argentina

R. Mangupli

Hospital Universitario, Caracas, Venezuela

L. Portocarrero

Instituto Nacional de Neurologia y Neurocirugia, Mexico City, Mexico

M. Sheppard

The University of Birmingham, Birmingham, UK 
Keywords Acromegaly - Growth hormone .

Insulin-like growth factor 1 - Latin America - Octreotide . Radiotherapy $\cdot$ Somatostatin receptors $\cdot$ Surgery

\section{Introduction}

In August 2007, a panel of neuroendocrinologists from Latin America, the United States of America and the United Kingdom convened in Mexico City to discuss the diagnosis, treatment and follow-up of patients with acromegaly, with a specific focus on Latin America. One of the greatest challenges in providing consensus recommendations in this region is the diversity in this large population of more than 550 million. Furthermore, a range of management approaches may not be available for many patients with acromegaly and the feasibility and cost should be considered in the implementation of local guidelines. Therefore, this meeting was conducted with the aim of providing recommendations for the management of patients with acromegaly in Latin America, and this review highlights the main conclusions reached during this meeting.

\section{Diagnostic criteria}

The panel discussed the criteria used to make a diagnosis of acromegaly and the clinical approaches in cases where a discrepancy between growth hormone $(\mathrm{GH})$ and insulinlike growth factor-1 (IGF-1) measurements are seen. According to the diagnostic criteria proposed at the Cortina consensus, a random GH level lower than $0.4 \mu \mathrm{g} / \mathrm{l}$ and an IGF-1 level within the age- and sex-matched normal range excludes the diagnosis of acromegaly in a patient with no other concurrent illness [1]. If there is clinical suspicion of acromegaly and either of these levels are not achieved, an oral glucose tolerance test (OGTT) should be performed with $75 \mathrm{~g}$ of oral glucose, with subsequent measurements of glucose and GH every 30 min over $2 \mathrm{~h}$; a fall in $\mathrm{GH}$ level to $\leq 1 \mu \mathrm{g} / \mathrm{l}$ and a normal IGF-1 level excludes the diagnosis of acromegaly. The group acknowledged the fact that with the currently used ultrasensitive GH assays, a normal GH suppression by glucose is considerably below $1 \mu \mathrm{g} / \mathrm{l}$ and speculated about the appropriateness of lowering the cutoff to $0.6 \mu \mathrm{g} / \mathrm{l}$.

Despite the advances in biochemical assays and the definition of cutoff levels for both GH and IGF-1, major limitations in the diagnostic assessment of acromegaly still exist [2]. Several factors make the biochemical diagnosis of acromegaly challenging, including the pulsatile nature of GH secretion, the sensitivity of GH secretion to sleep, and changes in the secretion of the hormone according to the age and nutritional status of the patient [3]. Assessment of GH and IGF-1 levels are also made difficult by the lack of uniformity in reference standards and analysis [4], which result in poor reproducibility and wide variation, in particular for IGF-1 [5-7], and make the diagnosis of acromegaly more challenging. Indeed, several authors have found an overlap between the biochemical results in healthy volunteers and in patients with acromegaly if the criterion of a GH nadir of $<1 \mu \mathrm{g} / \mathrm{l}$ during an OGTT was used $[8,9]$.

Given the difficulties in assessing GH and IGF-1 levels, the panel recommended that random GH levels should not be used as a diagnostic tool in acromegaly. Ideally, each laboratory should attempt to standardize age- and sexmatched IGF-1 reference values and establish its own cutoff point. Also, an attempt should be made to certify assays with appropriate biological standards. Notably, even if IGF-1 levels are very high and the clinical picture of acromegaly is clear, GH evaluation during OGTT at diagnosis could be useful, since follow-up management should be taken into consideration. Furthermore, the panel supported the use of an OGTT (using a GH nadir of $<1 \mu \mathrm{g} / \mathrm{l}$ ) in patients where there was a discrepancy between IGF-1 levels and the clinical picture. The panel also highlighted that extreme caution should be exercised when employing this test in patients exhibiting glucose intolerance.

\section{First-line therapy}

The panel addressed the issue of when treatment with somatostatin analogues or surgery should be considered. Generally, surgery is indicated for GH-secreting microadenomas, resectable macroadenomas and for decompression of vital structures, particularly the optic tracts [3]. While cure rates with surgical resection can be as high as $90 \%$ in patients with a microadenoma and approximately 50\% in patients harboring a macroadenoma, they are lower if the adenoma is invasive [10,11]. Despite the known benefits of transsphenoidal resection by experienced surgeons for small pituitary adenomas [12], patients with larger adenomas (e.g. $>20 \mathrm{~mm}$ ) and a preoperative $\mathrm{GH}$ level greater than $50 \mu \mathrm{g} / \mathrm{l}$ may also require medical and, sometimes, radiation therapy to control $\mathrm{GH}$ hypersecretion $[10,13]$. Many patients with acromegaly in Latin America present with large, often inoperable tumors that are not confined to the sella turcica and therefore cannot be cured by surgery alone.

First-line medical therapy has improved over the last decade, and first-line therapy with somatostatin analogues is now considered a viable alternative to surgery in selected patients [14]. Success rates for octreotide LAR as first-line therapy for acromegaly have been reported to range from 
40 to $80 \%$ for the achievement of a 'safe' $\mathrm{GH}$ level of $2-2.5 \mu \mathrm{g} / \mathrm{l}$, and from 30 to $65 \%$ for the normalization of IGF-1 $[15,16]$. Although there are fewer reported studies concerning lanreotide Autogel as first-line therapy for acromegaly, a recent study in which 26 newly diagnosed patients were treated with lanreotide Autogel for 12 months found that $58 \%$ of patients achieved a GH level $\leq 1.9 \mu \mathrm{g} / \mathrm{l}$, and $58 \%$ of patients had normalized IGF-1 [17]. In addition to biochemical control, first-line therapy with octreotide LAR has been shown to significantly reduce tumor size in approximately $80 \%$ of patients [18, 19], and recent studies suggest octreotide LAR can also provide long-term biochemical and tumor volumetric control [20, 21]. Moreover, a recent prospective trial including patients from Latin America has suggested that octreotide LAR represents a viable alternative to surgery for the primary treatment of acromegaly [16].

Although the panel advocated the use of first-line medical therapy in patients with acromegaly, they acknowledged that access to somatostatin analogues is a key issue in Latin America, as treatment is not always subsidized by government agencies. However, this situation varies not only between countries but also within countries. Therefore, health economic analyses are warranted in this region. Physicians in Latin America should tailor appropriate treatments or combinations for each patient based on the clinical presentation and availability of resources (Fig. 1). As a general rule, however, the panel recommended that tumor resection performed by an experienced pituitary neurosurgeon should be the first option in patients with a microadenoma or a resectable macroadenoma, as well as in patients with an invasive macroadenoma and visual field defects. Initial surgical therapy could also be indicated for some patients with large invasive tumors to reduce the tumor mass (debulking) and, consequently, reduce $\mathrm{GH}$ and
IGF-1 levels (albeit without achieving normalization) for the following reasons: (a) unavailability of somatostatin analogues (which is a reality in some countries in Latin America) and; (b) improve the response to medical treatment [22, 23] and radiotherapy [24].

First-line medical therapy should be indicated for patients who are not willing to undergo, or are not fit for surgery, as well as in those whose tumor has invaded the cavernous sinus or in whom surgical debulking is not feasible. For cases not falling within the above categories, judgment is required to indicate the first-line therapy, taking into account the local experience and availability of resources.

\section{Management and optimization of treatment with somatostatin analogues}

There is now convincing evidence that octreotide LAR is a well-tolerated and effective medical therapy for patients with acromegaly [16, 21, 25-28]. The panel discussed the dose that should be used and how this dose should be modified in clinical practice. Although an acute test dose of subcutaneous octreotide is used in some centers, [29] the panel agreed that this acute test is generally not predictive of a long-term response to octreotide LAR. Early dosefinding studies of octreotide LAR suggested that one injection of either the 20 or $30 \mathrm{mg}$ dose may provide biochemical control of the disease for up to 4 and 6 weeks, respectively [27, 30]. More recently, it has been suggested that the variability in individual patient responses to depot somatostatin analogues requires individual dose titration and careful assessment of the optimal dose and injection interval [31-34]. Therefore, it is recommended that patients initiate treatment with octreotide LAR $20 \mathrm{mg}$
Fig. 1 Suggested algorithm for choosing first-line therapy in Latin American patients with newly diagnosed acromegaly

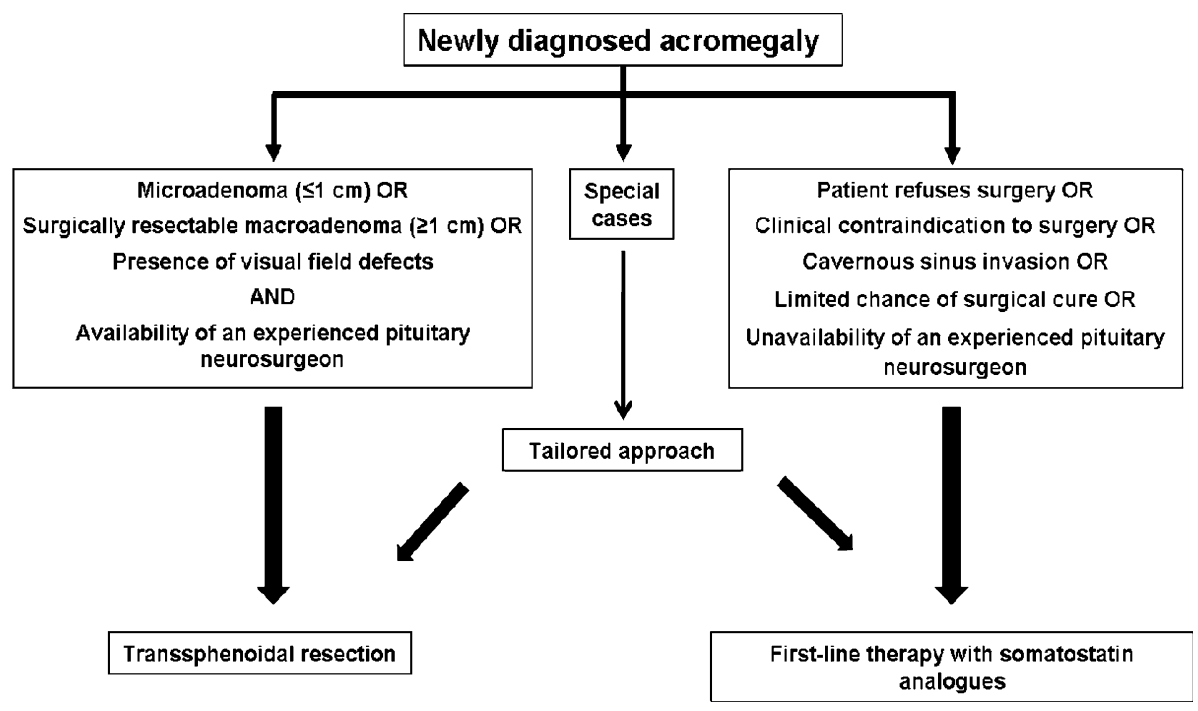


every 28 days, with evaluation of biochemical control after 3 or 6 months. For those patients with uncontrolled disease after 3-6 months, the dose should be increased to $30 \mathrm{mg}$ every 28 days. The maximum dose of octreotide LAR used in clinical practice is typically 30 or $40 \mathrm{mg}$ every 4 weeks. Despite limited data on the efficacy of the $40 \mathrm{mg}$ dose among patients not responding to the $30 \mathrm{mg}$ dose, some studies have suggested that increasing the dose of octreotide LAR to $40 \mathrm{mg}$ in these patients may result in enhanced suppression of GH and IGF-1 levels without additional toxicity $[33,35]$.

In patients well controlled with octreotide LAR (normal serum GH and IGF-1 levels), two different approaches may be considered. The first is to reduce the dose (from 30 to $20 \mathrm{mg}$, or from 20 to $10 \mathrm{mg}$, for example), keeping the same dose interval [36]. Secondly, increasing the injection interval of octreotide LAR treatment from 4 to 6 weeks may be feasible [37].

Similarly, lanreotide Autogel may be initiated at a dose of $90 \mathrm{mg}$ every 28 days, and then titrated up to $120 \mathrm{mg}$ or down to 60 mg every 28 days after 3-6 months depending on the level of biochemical control. There is also some evidence that the dose interval of lanreotide Autogel may be extended in patients with biochemical control [38].

Despite the controversy associated with the monitoring of patients treated with somatostatin analogue therapy, an algorithm recently proposed by a group in Oxford, UK used GH levels of $2.5 \mu \mathrm{g} / \mathrm{l}$ as an indication of biochemical control [32]. There are many reports stating that both GH and/or IGF-1 are important for achieving disease control [39-43] and, as discussed, there are known limitations regarding their measurement [3]. Because of these limitations, the most reliable evaluation to confirm disease control would be to assess both GH and IGF-1 values [44]. Therefore, the panel recommended using IGF-1 levels for decisions regarding the appropriateness of dose and injection interval, GH levels (either basal or an average of 5-6 h consecutive measurements) to monitor medical therapy, and GH levels after OGTT to assess cure or disease control after surgery (and when IGF-1 values and the clinical picture are discrepant). Although a 3-month interval for biochemical assessment was considered appropriate in most cases, the panel emphasized that IGF-1 levels may take longer to return to normal than $\mathrm{GH}$ levels.

\section{Combining and changing medical therapy}

The next issue addressed by the panel was uncontrolled disease in patients who had received optimal doses of somatostatin analogues and maximal surgical debulking. Approximately one-third of patients with acromegaly treated with somatostatin analogues for prolonged periods of time do not achieve safe levels of GH or a normalization of serum IGF-1 levels, and such lack of control is thought to be related to the type and density of somatostatin receptor subtype (sst) expression in the tumor [45]. Therefore, the panel recommendations below (Fig. 2) are applicable to patients whose disease remains uncontrolled by maximal somatostatin analogue therapy equivalent to monthly octreotide LAR doses of 30 or $40 \mathrm{mg}$.

Cabergoline is a dopamine agonist with a potent and longlasting action, as well as an acceptable safety profile, when compared with bromocriptine [46]. Studies of single-agent cabergoline administered as weekly doses ranging from 1.0 to $3.5 \mathrm{mg}$, have demonstrated that cabergoline is effective in patients with and without prolactin cosecretion [46, 47]. However, it is currently unclear whether patients whose disease is resistant to somatostatin analogue therapy should receive cabergoline as a single agent or in combination with
Fig. 2 Suggested treatment algorithm for Latin American patients with acromegaly and no disease control after maximal surgical debulking and somatostatin analogue therapy. * Because pegvisomant is not available in all Latin American countries, radiotherapy might be considered as an additional treatment option for patients not controlled after maximal doses of somatostatin analogues and/ or cabergoline

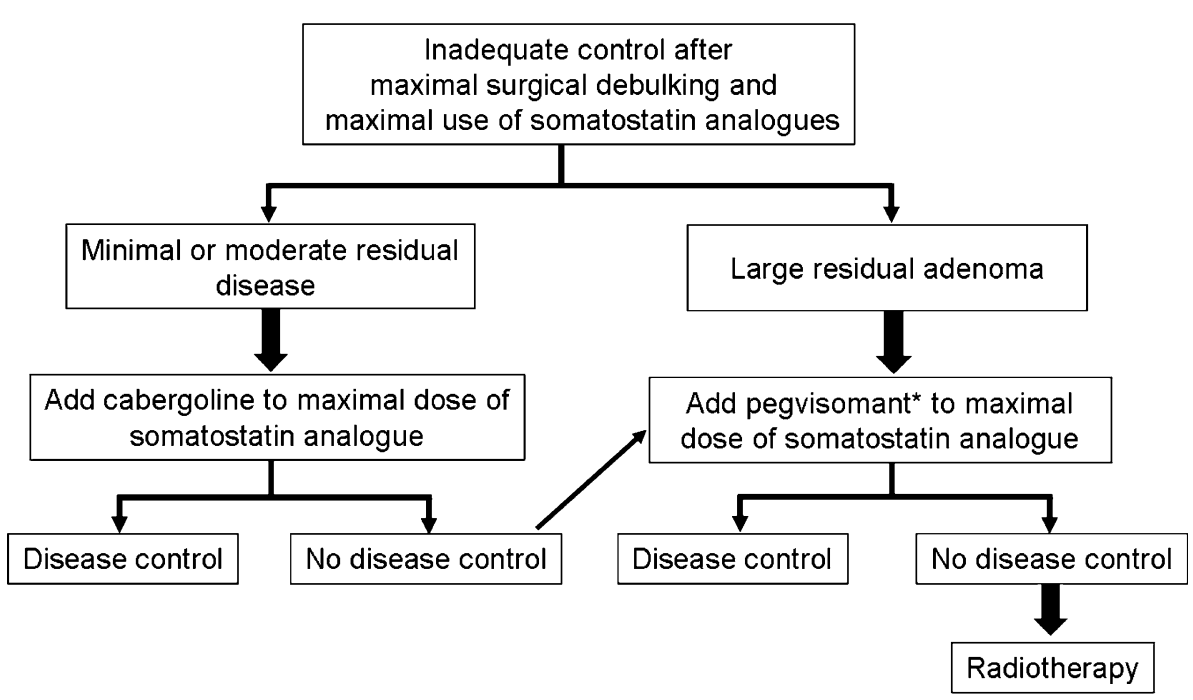


a somatostatin analogue. Despite the preliminary evidence of prolonged biochemical control in patients responding to somatostatin analogues in whom therapy is withdrawn $[48,49]$, there is anecdotal evidence of a worsening in biochemical parameters when somatostatin analogue therapy is withdrawn in patients whose disease is resistant to somatostatin analogues. Furthermore, studies using fluorescent resonance energy transfer techniques have demonstrated heterodimerization of somatostatin and dopamine receptors, providing a biological rationale for combination therapy trials [50]. In studies combining a somatostatin analogue with cabergoline, $42-50 \%$ of patients achieved normal IGF-1 levels; in addition, these studies have suggested that such responses do not correlate with serum levels or tissue expression of prolactin [51-53]. Although cabergoline is considered an attractive agent for combination therapy with octreotide LAR in patients with acromegaly in Latin America, at high doses there is an increased risk of cardiac valvular abnormalities [54, 55]. Patients with acromegaly treated with cabergoline should therefore undergo periodic echocardiographic monitoring.

Pegvisomant, a GH receptor antagonist, represents a further addition to the medical arsenal against acromegaly [56]. Among patients treated primarily with surgery followed by medical therapy and/or radiation therapy, daily administration of pegvisomant has been shown to normalize IGF-1 and provide clinical control of acromegaly in a large number of patients [57]. In addition, pegvisomant has shown activity among patients whose disease was not adequately controlled by somatostatin analogue therapy $[58,59]$. The major disadvantages of pegvisomant are its high cost, the fact that it does not act directly on the cause of the disease (the pituitary tumor) and the increased risk of elevated liver transaminase levels. Feenstra et al. [60] assessed the combination of a somatostatin analogue once monthly and pegvisomant once weekly in 26 patients with active acromegaly and concluded that pegvisomant was effective and could significantly reduce the costs of medical treatment for acromegaly (in comparison to monotherapy with pegvisomant) in a proportion of patients whose disease is not fully controlled by somatostatin analogue therapy. The feasibility of widely implementing such a strategy in patients with acromegaly in Latin America remains unknown, although pegvisomant should be considered in selected cases when resources are available. Finally, other medical options for somatostatin analogue-resistant acromegaly may become available in the near future, including agents with multiple sst activity (such as pasireotide [SOM230] which has high affinity for sst $_{1,2,3}$ and sst $_{5}$ ) [61], agents with selective affinity for sst $_{2}$ and sst $_{5}$ (such as BIM-23244) [62], and chimeric somatostatin-dopamine receptor agonists (such as BIM-23A387) [63].

\section{Patient follow-up after surgical resection}

The panel discussion focused on the types of, and frequency with which, laboratory and imaging studies should be carried out after surgery with curative intent during follow-up. Currently, there is considerable controversy surrounding this issue, despite the availability of published guidelines regarding postoperative follow-up [1, 64]. From a biochemical perspective, patient classification into 'active disease' and 'inactive disease' categories may be more appropriate than the use of terms such as 'cure', 'remission', and 'persistence' of the disease. However, it is currently unclear whether patient categorization based on early evaluation, e.g. between 1 and 3 months postoperatively, is of value, as a study in Mexico found that nearly $30 \%$ of patients changed their initial category during follow-up [65]. Also, it is currently uncertain whether patients with normal IGF-1 levels and inadequate GH suppression after an OGTT are at higher risk for recurrent disease activity [66].

With regard to the classification of active versus inactive disease, the panel recommended assessing patients for 3 months postoperatively, using IGF-1 and GH levels as the main indicator of disease control, as although IGF-1 levels usually stabilize within 3 months after surgery, on rare occasions this may take up to 12 months [64]. Measurement of GH levels after an OGGT should be reserved for cases where there is some uncertainty, and discordant biochemical results may help tailor the interval of followup, which should also be dictated by patient convenience. As a general rule, follow-up during the first year should be performed every 3-6 months, and at least a yearly followup is indicated during the first 3 years, but patients should be monitored for life. In addition, lifelong evaluation is recommended for most patients with acromegaly and inactive disease, since recurrences as late as 10-15 years post surgery have been reported [67, 68]. Magnetic resonance imaging should be carried out 6-12 months after surgery, and repeated only when the results of clinical and biochemical evaluation during follow-up suggest a recurrence, given that this approach appears safe in patients with adequate biochemical control of acromegaly [69].

\section{The role of radiotherapy}

In the past, radiotherapy has played an important role in the management of patients with acromegaly. In fact, despite some controversy regarding its efficacy and safety, it is still used in some centers, particularly in Latin America, because of its low cost. Although the introduction of effective medical treatment for acromegaly has reduced the interest in radiotherapy, this is often the only available 
option. So rather than disqualifying radiotherapy, the panel reviewed the available data regarding its performance as a therapeutic tool in acromegaly. Although the efficacy of radiotherapy has been questioned by some studies [70, 71], a retrospective study by the UK National Acromegaly Register involving 884 patients, 111 of whom had IGF-1 levels assessed on follow-up, found a steady increase in the proportion of patients achieving normalization of IGF-1 levels: $38 \%$ at 2 years, $50 \%$ at 5 years, and $56 \%$ at 15 years [72]. However, there are known adverse events associated with radiotherapy in patients with acromegaly, including visual loss or deterioration, brain necrosis and vascular complications, secondary tumor formation, hypopituitarism, and neuropsychological damage. It is noteworthy that these adverse effects are minimized when using modern techniques of pituitary irradiation, such as the gamma knife. Therefore, the panel recommendation was to consider radiotherapy for patients with acromegaly who have persistently active disease after pituitary surgery and fully optimized medical therapy (Fig. 2) and for those operated, uncontrolled patients who have no access to somatostatin analogues. The specific type of radiotherapy, including its modality and schedule, should be guided by local availability and expertise.

\section{Concluding remarks}

The treatment of patients with acromegaly has undergone profound changes in the past decade, largely because of the introduction of effective medical interventions that may be used as first-line therapy in selected cases. Although surgical resection remains the mainstay of therapy for small and potentially resectable pituitary macroadenomas, medical interventions represent a valuable adjunct to the therapeutic arsenal. Radiotherapy may be indicated in selected cases when no disease control is achieved despite optimal surgical debulking and medical therapy, when there is no access to somatostatin analogues, or cost considerations are paramount. Local issues of cost, availability and expertise of neurosurgeons will dictate treatment choice, which should also be tailored according to patient preferences and characteristics. In addition, laboratory evaluation plays an important role in the diagnosis and management of patients with acromegaly, and constant improvements and standardizations of age- and sex-matched reference values are required by local institutions. Finally, physicians in Latin America should adapt their clinical management of patients with acromegaly to the available diagnostic tools and therapeutic options, in order to achieve the best treatment outcome.

Acknowledgments This workshop was funded by a grant from Novartis Pharmaceuticals Corporation, East Hanover, New Jersey.
The authors thank Keri Wellington, $\mathrm{PhD}$, for medical editorial assistance with this article. Financial support for medical editorial assistance was provided by Novartis Pharmaceuticals Corporation.

Open Access This article is distributed under the terms of the Creative Commons Attribution Noncommercial License which permits any noncommercial use, distribution, and reproduction in any medium, provided the original author(s) and source are credited.

\section{References}

1. Giustina A, Barkan A, Casanueva FF, Cavagnini F, Frohman L, Ho K, Veldhuis J, Wass J, von Werder K, Melmed S (2000) Criteria for cure of acromegaly: a consensus statement. J Clin Endocrinol Metab 85:526-529

2. Freda PU (2003) Pitfalls in the biochemical assessment of acromegaly. Pituitary 6:135-140

3. Melmed S (2006) Medical progress: acromegaly. N Engl J Med 355:2558-2573

4. Strasburger CJ, Bidlingmaier M (2005) How robust are laboratory measures of growth hormone status? Horm Res 64(Suppl 2): $1-5$

5. Pokrajac A, Wark G, Ellis AR, Wear J, Wieringa GE, Trainer PJ (2007) Variation in GH and IGF-I assays limits the applicability of international consensus criteria to local practice. Clin Endocrinol (Oxf) 67:65-70

6. Milani D, Carmichael JD, Welkowitz J, Ferris S, Reitz RE, Danoff A, Kleinberg DL (2004) Variability and reliability of single serum IGF-I measurements: impact on determining predictability of risk ratios in disease development. J Clin Endocrinol Metab 89:2271-2274

7. Brabant G (2003) Insulin-like growth factor-I: marker for diagnosis of acromegaly and monitoring the efficacy of treatment. Eur J Endocrinol 148(Suppl 2):S15-S20

8. Freda PU, Reyes CM, Nuruzzaman AT, Sundeen RE, Bruce JN (2003) Basal and glucose-suppressed GH levels less than 1 microg/L in newly diagnosed acromegaly. Pituitary 6:175-180

9. Dimaraki EV, Jaffe CA, Mott-Friberg R, Chandler WF, Barkan AL (2002) Acromegaly with apparently normal GH secretion: implications for diagnosis and follow-up. J Clin Endocrinol Metab 87:3537-3542

10. Nomikos P, Buchfelder M, Fahlbusch R (2005) The outcome of surgery in 668 patients with acromegaly using current criteria of biochemical 'cure'. Eur J Endocrinol 152:379-387

11. Trepp R, Stettler C, Zwahlen M, Seiler R, Diem P, Christ ER (2005) Treatment outcomes and mortality of 94 patients with acromegaly. Acta Neurochir (Wien) 147:243-251

12. Gittoes NJ, Sheppard MC, Johnson AP, Stewart PM (1999) Outcome of surgery for acromegaly-the experience of a dedicated pituitary surgeon. QJM 92:741-745

13. Shimon I, Cohen ZR, Ram Z, Hadani M (2001) Transsphenoidal surgery for acromegaly: endocrinological follow-up of 98 patients. Neurosurgery 48:1239-1243

14. Melmed S, Colao A, Barkan A, Molitch M, Grossman AB, Kleinberg D, Clemmons D, Chanson P, Laws E, Schlechte J, Vance ML, Ho K, Giustina A (2009) Guidelines for acromegaly management: an update. J Clin Endocrinol Metab 94:1509-1517

15. Freda PU (2002) Somatostatin analogs in acromegaly. J Clin Endocrinol Metab 87:3013-3018

16. Mercado M, Borges F, Bouterfa H, Chang TC, Chervin A, Farrall AJ, Patocs A, Petersenn S, Podoba J, Safari M, Wardlaw J (2007) A prospective, multicentre study to investigate the efficacy, safety and tolerability of octreotide LAR (long-acting repeatable 
octreotide) in the primary therapy of patients with acromegaly. Clin Endocrinol (Oxf) 66:859-868

17. Colao A, Auriemma RS, Rebora A, Galdiero M, Resmini E, Minuto F, Lombardi G, Pivonello R, Ferone D (2009) Significant tumour shrinkage after 12 months of Lanreotide Autogel-120 mg treatment given first-line in acromegaly. Clin Endocrinol (Oxf) $71: 237-245$

18. Bevan JS (2005) The antitumoral effects of somatostatin analog therapy in acromegaly. J Clin Endocrinol Metab 90:1856-1863

19. Cook D (2009) Octreotide long-acting repeatable in acromegaly: achieving optimal control. The Endocrinologist 19:142-147

20. Ayuk J, Stewart SE, Stewart PM, Sheppard MC (2002) Longterm safety and efficacy of depot long-acting somatostatin ana$\operatorname{logs}$ for the treatment of acromegaly. J Clin Endocrinol Metab $87: 4142-4146$

21. Cozzi R, Montini M, Attanasio R, Albizzi M, Lasio G, Lodrini S, Doneda P, Cortesi L, Pagani G (2006) Primary treatment of acromegaly with octreotide LAR: a long-term (up to 9 years) prospective study of its efficacy in the control of disease activity and tumor shrinkage. J Clin Endocrinol Metab 91:1397-1403

22. Colao A, Attanasio R, Pivonello R, Cappabianca P, Cavallo LM, Lasio G, Lodrini A, Lombardi G, Cozzi R (2006) Partial surgical removal of GH-secreting pituitary tumors enhances the response to somatostatin analogues in acromegaly. J Clin Endocrinol Metab 91:85-92

23. Jallad RS, Musolino NR, Kodaira S, Cescato VA, Bronstein MD (2007) Does partial surgical tumour removal influence the response to octreotide-LAR in acromegalic patients previously resistant to the somatostatin analogue? Clin Endocrinol (Oxf) 67:310-315

24. Jallad RS, Musolino NR, Salgado LR, Bronstein MD (2007) Treatment of acromegaly: is there still a place for radiotherapy? Pituitary 10:53-59

25. Colao A, Pivonello R, Rosato F, Tita P, De Menis E, Barreca A, Ferrara R, Mainini F, Arosio M, Lombardi G (2006) First-line octreotide-LAR therapy induces tumor shrinkage and controls hormone excess in patients with acromegaly: results from an open, prospective, multicentre trial. Clin Endocrinol (Oxf) 64:342-351

26. Jallad RS, Musolino NR, Salgado LR, Bronstein MD (2005) Treatment of acromegaly with octreotide-LAR: extensive experience in a Brazilian institution. Clin Endocrinol (Oxf) 63: 168-175

27. Stewart PM, Kane KF, Stewart SE, Lancranjan I, Sheppard MC (1995) Depot long-acting somatostatin analog (Sandostatin-LAR) is an effective treatment for acromegaly. J Clin Endocrinol Metab 80:3267-3272

28. Mangupli R, Lisette A, Ivett C, Paul C, de los Rios V, Luis CJ (2003) Improvement of acromegaly after octreotide LAR treatment. Pituitary 6:29-34

29. Taboada GF, Donangelo I, Guimaraes RF, Silva MO, Fontes R, Gadelha MR (2005) Acute test with subcutaneous octreotide as a predictor of the response to treatment with octreotide LAR. Arq Bras Endocrinol Metabol 49:390-395

30. Flogstad AK, Halse J, Haldorsen T, Lancranjan I, Marbach P, Bruns C, Jervell J (1995) Sandostatin LAR in acromegalic patients: a dose-range study. J Clin Endocrinol Metab 80:36013607

31. Jenkins PJ, Akker S, Chew SL, Besser GM, Monson JP, Grossman AB (2000) Optimal dosage interval for depot somatostatin analogue therapy in acromegaly requires individual titration. Clin Endocrinol (Oxf) 53:719-724

32. Turner HE, Thornton-Jones VA, Wass JA (2004) Systematic dose-extension of octreotide LAR: the importance of individual tailoring of treatment in patients with acromegaly. Clin Endocrinol (Oxf) 61:224-231
33. Colao A, Pivonello R, Auriemma RS, Galdiero M, Savastano S, Lombardi G (2007) Beneficial effect of dose escalation of Octreotide-LAR as first-line therapy in patients with acromegaly. Eur J Endocrinol 157:579-587

34. Attanasio R, Lanzi R, Losa M, Valentini F, Grimaldi F, De ME, Davi MV, Battista C, Castello R, Cremonini N, Razzore P, Rosato F, Montini M, Cozzi R (2008) Effects of lanreotide Autogel on growth hormone, insulinlike growth factor 1 , and tumor size in acromegaly: a 1-year prospective multicenter study. Endocr Pract 14:846-855

35. Yetkin DO, Boysan SN, Tiryakioglu O, Yalin AS, Kadioglu P (2007) Forty-month follow-up of persistent and difficultly controlled acromegalic patients treated with depot long acting somatostatin analog octreotide. Endocr J 54:459-464

36. Lancranjan I, Atkinson AB (1999) Results of a European multicentre study with Sandostatin LAR in acromegalic patients. Sandostatin LAR Group. Pituitary 1:105-114

37. Biermasz NR, van den Oever NC, Frolich M, Arias AM, Smit JW, Romijn JA, Roelfsema F (2003) Sandostatin LAR in acromegaly: a 6-week injection interval suppresses GH secretion as effectively as a 4-week interval. Clin Endocrinol (Oxf) 58:288-295

38. Lucas T, Astorga R, The Spanish-Portuguese Multicentre Autogel Study Group on Acromegaly (2006) Efficacy of lanreotide Autogel administered every $4-8$ weeks in patients with acromegaly previously responsive to lanreotide microparticles $30 \mathrm{mg}$ : a phase III trial. Clin Endocrinol (Oxf) 65:320-326

39. Ayuk J, Clayton RN, Holder G, Sheppard MC, Stewart PM, Bates AS (2004) Growth hormone and pituitary radiotherapy, but not serum insulin-like growth factor-I concentrations, predict excess mortality in patients with acromegaly. J Clin Endocrinol Metab 89:1613-1617

40. Kauppinen-Makelin R, Sane T, Reunanen A, Valimaki MJ, Niskanen L, Markkanen H, Loyttyniemi E, Ebeling T, Jaatinen P, Laine H, Nuutila P, Salmela P, Salmi J, Stenman UH, Viikari J, Voutilainen E (2005) A nationwide survey of mortality in acromegaly. J Clin Endocrinol Metab 90:4081-4086

41. Ayuk J, Sheppard MC (2007) Does acromegaly enhance mortality? Rev Endocr Metab Disord 9:33-39

42. Colao A, Terzolo M, Bondanelli M, Galderisi M, Vitale G, Reimondo G, Ambrosio MR, Pivonello R, Lombardi G, Angeli A, degli Uberti EC (2008) GH and IGF-I excess control contributes to blood pressure control: results of an observational, retrospective, multicentre study in 105 hypertensive acromegalic patients on hypertensive treatment. Clin Endocrinol (Oxf) 69:613-620

43. Puder JJ, Nilavar S, Post KD, Freda PU (2005) Relationship between disease-related morbidity and biochemical markers of activity in patients with acromegaly. J Clin Endocrinol Metab 90:1972-1978

44. Brooke AM, Drake WM (2007) Serum IGF-I levels in the diagnosis and monitoring of acromegaly. Pituitary 10:173-179

45. Bronstein MD (2006) Acromegaly: molecular expression of somatostatin receptor subtypes and treatment outcome. Front Horm Res 35:129-134

46. Jackson SN, Fowler J, Howlett TA (1997) Cabergoline treatment of acromegaly: a preliminary dose finding study. Clin Endocrinol (Oxf) 46:745-749

47. Abs R, Verhelst J, Maiter D, Van Acker K, Nobels F, Coolens JL, Mahler C, Beckers A (1998) Cabergoline in the treatment of acromegaly: a study in 64 patients. J Clin Endocrinol Metab 83:374-378

48. Lorcy Y, Dejager S, Chanson P (2000) Time course of GH and IGF-1 levels following withdrawal of long-acting octreotide in acromegaly. Pituitary 3:193-197

49. Ronchi CL, Rizzo E, Lania AG, Pivonello R, Grottoli S, Colao A, Ghigo E, Spada A, Arosio M, Beck-Peccoz P (2008) Preliminary 
data on biochemical remission of acromegaly after somatostatin analogs withdrawal. Eur J Endocrinol 158:19-25

50. Rocheville M, Lange DC, Kumar U, Patel SC, Patel RC, Patel YC (2000) Receptors for dopamine and somatostatin: formation of hetero-oligomers with enhanced functional activity. Science 288:154-157

51. Cozzi R, Attanasio R, Lodrini S, Lasio G (2004) Cabergoline addition to depot somatostatin analogues in resistant acromegalic patients: efficacy and lack of predictive value of prolactin status. Clin Endocrinol (Oxf) 61:209-215

52. Gatta B, Hau DH, Catargi B, Roger P, Tabarin A (2005) Re-evaluation of the efficacy of the association of cabergoline to somatostatin analogues in acromegalic patients. Clin Endocrinol (Oxf) 63:477-478

53. Selvarajah D, Webster J, Ross R, Newell-Price J (2005) Effectiveness of adding dopamine agonist therapy to long-acting somatostatin analogues in the management of acromegaly. Eur $\mathbf{J}$ Endocrinol 152:569-574

54. Schade R, Andersohn F, Suissa S, Haverkamp W, Garbe E (2007) Dopamine agonists and the risk of cardiac-valve regurgitation. N Engl J Med 356:29-38

55. Zanettini R, Antonini A, Gatto G, Gentile R, Tesei S, Pezzoli G (2007) Valvular heart disease and the use of dopamine agonists for Parkinson's disease. N Engl J Med 356:39-46

56. Ayuk J, Sheppard MC (2004) The role of growth hormonereceptor antagonism in relation to acromegaly. Expert Opin Pharmacother 5:2279-2285

57. Trainer PJ, Drake WM, Katznelson L, Freda PU, Herman-Bonert V, van der Lely AJ, Dimaraki EV, Stewart PM, Friend KE, Vance ML, Besser GM, Scarlett JA, Thorner MO, Parkinson C, Klibanski A, Powell JS, Barkan AL, Sheppard MC, Malsonado M, Rose DR, Clemmons DR, Johannsson G, Bengtsson BA, Stavrou S, Kleinberg DL, Cook DM, Phillips LS, Bidlingmaier M, Strasburger CJ, Hackett S, Zib K, Bennett WF, Davis RJ (2000) Treatment of acromegaly with the growth hormone-receptor antagonist pegvisomant. N Engl J Med 342:1171-1177

58. Colao A, Pivonello R, Auriemma RS, De Martino MC, Bidlingmaier M, Briganti F, Tortora F, Burman P, Kourides IA, Strasburger CJ, Lombardi G (2006) Efficacy of 12-month treatment with the $\mathrm{GH}$ receptor antagonist pegvisomant in patients with acromegaly resistant to long-term, high-dose somatostatin analog treatment: effect on IGF-I levels, tumor mass, hypertension and glucose tolerance. Eur J Endocrinol 154:467-477

59. Herman-Bonert VS, Zib K, Scarlett JA, Melmed S (2000) Growth hormone receptor antagonist therapy in acromegalic patients resistant to somatostatin analogs. J Clin Endocrinol Metab $85: 2958-2961$

60. Feenstra J, de Herder WW, ten Have SM, van den Beld AW, Feelders RA, Janssen JA, van der Lely AJ (2005) Combined therapy with somatostatin analogues and weekly pegvisomant in active acromegaly. Lancet 365:1644-1646

61. Schmid HA (2008) Pasireotide (SOM230): Development, mechanism of action and potential applications. Mol Cell Endocrinol 286:69-74
62. Saveanu A, Gunz G, Dufour H, Caron P, Fina F, Ouafik L, Culler MD, Moreau JP, Enjalbert A, Jaquet P (2001) Bim-23244, a somatostatin receptor subtype 2- and 5-selective analog with enhanced efficacy in suppressing growth hormone $(\mathrm{GH})$ from octreotide-resistant human GH-secreting adenomas. J Clin Endocrinol Metab 86:140-145

63. Jaquet P, Gunz G, Saveanu A, Dufour H, Taylor J, Dong J, Kim S, Moreau JP, Enjalbert A, Culler MD (2005) Efficacy of chimeric molecules directed towards multiple somatostatin and dopamine receptors on inhibition of $\mathrm{GH}$ and prolactin secretion from GH-secreting pituitary adenomas classified as partially responsive to somatostatin analog therapy. Eur $\mathrm{J}$ Endocrinol 153:135-141

64. Growth Hormone Research Society, Pituitary Society (2004) Biochemical assessment and long-term monitoring in patients with acromegaly: statement from a joint consensus conference of the Growth Hormone Research Society and the Pituitary Society. J Clin Endocrinol Metab 89:3099-3102

65. Espinosa-de-los-Monteros A, Sosa E, Cheng S, Ochoa R, Sandoval C, Guinto G, Mendoza V, Hernandez I, Molina M, Mercado M (2006) Biochemical evaluation of disease activity after pituitary surgery in acromegaly: a critical analysis of patients who spontaneously change disease status. Clin Endocrinol (Oxf) 64:245-249

66. Freda PU, Post KD, Powell JS, Wardlaw SL (1998) Evaluation of disease status with sensitive measures of growth hormone secretion in 60 postoperative patients with acromegaly. J Clin Endocrinol Metab 83:3808-3816

67. Biermasz NR, van Dulken H, Roelfsema F (2000) Ten-year follow-up results of transsphenoidal microsurgery in acromegaly. J Clin Endocrinol Metab 85:4596-4602

68. Swearingen B, Biller BM, Barker FG, Katznelson L, Grinspoon S, Klibanski A, Zervas NT (1999) Long-term mortality after transsphenoidal surgery for Cushing disease. Ann Intern Med 130:821-824

69. Zirkzee EJ, Corssmit EP, Biermasz NR, Brouwer PA, WiggersDe Bruine FT, Kroft LJ, Van Buchem MA, Roelfsema F, Pereira AM, Smit JW, Romijn JA (2004) Pituitary magnetic resonance imaging is not required in the postoperative follow-up of acromegalic patients with long-term biochemical cure after transsphenoidal surgery. J Clin Endocrinol Metab 89:4320-4324

70. Barkan AL, Halasz I, Dornfeld KJ, Jaffe CA, Friberg RD, Chandler WF, Sandler HM (1997) Pituitary irradiation is ineffective in normalizing plasma insulin-like growth factor I in patients with acromegaly. J Clin Endocrinol Metab 82:31873191

71. Barkan AL (2003) Radiotherapy in acromegaly: the argument against. Clin Endocrinol (Oxf) 58:132-135

72. Jenkins PJ, Bates P, Carson MN, Stewart PM, Wass JA (2006) Conventional pituitary irradiation is effective in lowering serum growth hormone and insulin-like growth factor-I in patients with acromegaly. J Clin Endocrinol Metab 91:1239-1245 